\title{
THE WINE TOURISM TERROIR: EXPERIENCES FROM ISTRIA
}

\author{
Anita Silvana Ilak Peršurić \\ Ana Težak Damijanić \\ Zdravko Šergo
}

https://doi.org/10.20867/tosee.05.27

\begin{abstract}
Purpose - The purpose of the paper was to discover new ways of extending the tourist season through wine tourism. The survey detected which factors are crucial for wine, positive "push" motives of "tourism terroir", wine consumption and satisfaction with wine cellar visits.

Methodology - During the IPA/EFRR project "Malvasia TourIstra" a survey was conducted on two convenient samples. Wine cellar owners were selected by their production of high quality autochthonous wines with protected geographic origin. Wine cellar visitors were individual visitors at wine cellars. Two questionnaires were created as research tools for the survey. Findings - Our findings confirm critical factors of wine tourism, describe "push" and "pull" factors for Istria wine tourism, interest in wine itineraries and perceptions of autochthonous wine.

Contribution - Our findings might contribute to the development of innovative wine related tourist itineraries that can extend the tourist season.
\end{abstract}

Keywords tourism, wine tourism, wine tourists, wine, Istria

\section{INTRODUCTION}

In the widest context tourism involves a stay outside the usual place of residence which is often caused by some kind of motivation. In literature Dann $(1977,1981)$ described this motivation by “push” and "pull” factors. „Push“ factors are gateways from daily life, relaxation, prestige, socializing with family or others, while ,pull“ factors are destination features, attractions, offers of activities, products, new experiences, new knowledge about the destination.

Croatia as a destination has many and various features that can attract tourists for a shorter or longer stay. Beside the marketing schemes that present Croatia as a small land for a long vacation and Croatia as the Mediterranean as once upon a time, sea, sun and fun, numerous marketing promotions concern niche tourism (https://www.coloursofistria.com/en/destinations/istria). Examples of niche tourism in Croatia are health, wellness tourism, rural tourism, farm tourism, hunting tourism with complementary events (e.g. fairs and exhibitions of artisan and farm products such as wine, olive oil, brandies, chocolate, cheese etc.).

As a niche example of tourism, wine tourism complies also as a part of other types of niche tourism, such as rural tourism, farm tourism and coastal tourism (Yuan et al., 2005). The term "touristic terroir" refers to the combination of physical, cultural and natural environments (Hall and Mitchell, 2002). Terroir tourism presents a sense of place 
ToSEE - Tourism in Southern and Eastern Europe, Vol. 5, pp. 319-333, 2019

A. S. Ilak Peršurić, A. Težak Damijanić, Z. Šergo: THE WINE TOURISM TERROIR: EXPERIENCES ...

with its unique characteristics of territory, advertising, identity, plant growing (Marlowe and Lee, 2018). Wine tourism as one selective form of tourism attracts tourists to a destination with its main product - wine. The „push" factors are visits to the wine region, wine roads, wine producers, while simultaneously providing gateways from daily life, relaxation, socializing and prestige. The ,pull“ factors for wine tourism are wine as a product, visiting natural and cultural attractions in the wine production area / on wine roads, visiting wine producers (experiencing new products, getting acquaintance with the producers, acquainted knowledge about the production, wine varieties, types of wines), and learning about cultural and natural richness of the area.

\subsection{Wine Tourism, Wine and Terroir as Factors of Attraction}

Wine tourism as a part of tourism industry can attract new visitors interested in wine to the destination attracting them by visits to wineries, with culinary specialties, shopping, landscape and heritage (Gomez et al., 2013). Wine tourists can be attracted to a wine destination due to wine roads and viticulture landscapes (Tempesta et al., 2010, Ilak Peršurić, 2018), which can be presented also a rural idyll (Getz 2000; Getz and Brown 2006).

The concept of wine terroir in tourism is usually presented as a part of wine tourism, but in recent years as a novelty, some authors claim that wine tourism has its own terroir with distinctive differences for each and every wine region with unique wine varieties, landscapes, architecture, culture and heritage (Holland et al., 2014). A perspective of "terroir wine tourism" through a literature review of Marlow and Lee (2018) describes features such as viticulture terroir, viticulture, territory, advertising and identity. Kim and Bonn (2014) describe wine terroir authenticity as: "on-site", "location", "atmosphere", "production process", "labels", "varietal information", "explanations by staff", "expectations", "impressions", "friend/family", "freedom", "vintage information", "participation". The model proposed by Holland et al. (2014) sees terroir as summary of wine tourism product, viticulture, wine making and regional identity.

Wine as a product has certain attributes that attracts wine tourists to visit the destination and its wine areas and provoke them to taste, buy and purchase wine. The wine attributes are described usually as extrinsic and intrinsic attributes. Extrinsic attributes of wines are origin, grape variety, packaging, price, while intrinsic attributes are value for reputation, expert opinions, tasting ratings, appellation, and sensory values (Chrysochou and Jorgensen, 2016; Eldesouky and Mesias, 2014; Matos Graça Ramos et al., 2011). The wines that have a clearly represented origin (usually written on the bottle label) such as the wine region or geographically protected area where the wine was produced can attract the potential consumer as part of terroir. Since wine is a product with high involvement a consumer with higher level of knowledge about wine and those with wider sources of information can perceive a certain wine from a certain wine region more positively, which finally can be expressed with higher satisfaction with wine as a product and with higher satisfaction with the visit to the wine region as well. 
ToSEE - Tourism in Southern and Eastern Europe, Vol. 5, pp. 319-333, 2019

A. S. Ilak Peršurić, A. Težak Damijanić, Z. Šergo: THE WINE TOURISM TERROIR: EXPERIENCES ...

Therefore, labels that clearly state the wine region are very important and can lead a consumer toward understanding what is in the bottle even he or she never consume the wine before, an aspect important for tourists, especially first time visitors. The origin of wine can enhance the consumers subjective evaluation, while appellation / origin labels are official assurance of quality and authenticity (Chrysochou and Jorgensen, 2016) influencing the intent to purchase and consume the wine. Consumers perceive the reputation of a wine region and labels as a direct assurance of the wine quality (Combris et al., 2009, Gomez et al., 2013, Koch et al., 2013, Marzo-Navarro et al., 2012, Melo et al., 2010). Positive reputation of a wine region and its wines attract consumers in general terms and attract tourists as well. Lockshin et al. (2006) confirmed such consumer behavior, in which an average consumer facing unfamiliar wines and without previous knowledge about a wine will choose wine from a well-known region or a wine that has received a certain award or medal.

Because of these consumer behaviors the wines with regional features, especially wines from well-known wine regions with geographical identity, autochthonous wines and awarded wines can reach a better position compared to lesser known wine countries, regions and brands. Since wines with regional features, especially wines from wellknown wine regions with geographical identity, autochthonous wines and awarded wines have a better market position compared to wines produced in less known wine countries and regions, together stated, all these features provide good opportunities for Istria as a wine region and an excellent base for developing wine tourism.

\subsection{Wine Terroir in Istria}

According to the theoretical frame of Marlowe and Lee (2018) the "terroir wine tourism" contains five features; identity, advertising, territory, viticulture and viticulture terroir. Istria in the tourism sense has an identity of a coastal region with opportunities for vacationing at the seaside. The advertise of Istria presents colorful glimpses of blue sea and blue sky surrounded by green agricultural lands and woods. Furthermore, cities with stone walls, houses with colorful facades, and people in traditional costumes of peasants and fishermen are a part of Istria's image and identity

(https://www.coloursofistria.com/en/destinations/istria).

The territory of Istria for an average tourist, presents Istria as a destination with the ,pull“ factors comprising the offers of lodging facilities (e.g. hotels, camps, apartments, houses), activities (e.g. sports, cultural, gastronomic) and events (e.g. musical, traditional folklore, dance, events that presents traditional food and beverages). Offers provide numerous opportunities for novelties and new experiences (https://www.istra.hr/). Main motives for visiting rural parts of Istria County relates to the gastronomy offers of the destination and sightseeing natural and cultural sights (Ilak Peršurić, 2018).

The viticulture terroir of Istria is presented with its unique features as a part of rural Istria with its small medieval cities, stone houses and roads, facilities (rural houses and family farms with wine cellars), wine roads, vineyards, red soil, hardworking peasants, favorable climate, long sunny days and nearby seaside (http://www.vinistra.com/). 
ToSEE - Tourism in Southern and Eastern Europe, Vol. 5, pp. 319-333, 2019

A. S. Ilak Peršurić, A. Težak Damijanić, Z. Šergo: THE WINE TOURISM TERROIR: EXPERIENCES ...

In the image of Istria as a wine region (stated directly at the boarder lines; "Istria land of good wines") two main images are presented; autochthonous wine varieties Malvazija and Teran and hedonistic experiences connected to wine (e.g. wine fairs, pairing wine and food on sports cultural and music events, enjoying wine in fine dining restaurants, dinners with the wine producer etc., from http://www.istria-gourmet.com/hr/gurmanskidozivljaji).

The viticulture or plant growing terroir is based on production of autochthonous wine grapes. The most common planted variety is the white wine grape Malvazija Istarska which presents $80 \%$ of all Istrian vineyards (Ilak Peršurić et al., 2018). Malvazija is already recognized as a product interesting for tourists (Težak Damijanić et al., 2015) Beside Malvazija which is an autochthonous white wine grape variety, Teran as a red wine grape variety is also important for the wine terroir of Istria. Wine as a product is offered through gastronomic experiences on family farms and in local restaurants (in the rural areas), where the tourist encounters the local population.

Growing areas of these two main and autochthonous varieties are on moderately steep and gentle landscapes suitable for agricultural production - vineyards (on 200-300 m above sea level), in areas from the seaside to $30 \mathrm{~km}$ inland, with favorable microclimate (insolation, moisture), on red soils (Ilak Peršurić, 2018).

\section{MATERIALS AND METHODS}

During the project "Malvazija Tour Istra" 2014-2015., funded through the Operational Program of Cross-Border Cooperation IPA Slovenia Croatia the wine production, distribution, promotion channels, and sales of a sample of winemakers were examined. Secondary data were used from the Agency of Agricultural statistics for the period 20112014. Since no newer data were available, the time period covered by the last Agricultural Census was used.

Primary data were collected through field research and questionnaires' as research tools. One sample of wine producers and one sample of wine cellar visitors (tourists) were selected. The field research was executed in 2014 by visits to the wineries included in the project (the questionnaire was filled out by the project staff). The questionnaire for wine producers included open and closed type issues, classified in five parts (production, distribution channels, promotion, cross-border development and the characteristics of respondents). The sample consisted of 34 winemakers from Croatia (Istria). In the sample following features were examined: which types of wines were offered on the market, on which markets wine was sold (local, regional national, EU, world), which form of packing (bulk, bottles), and which types of wine types were in production (young, aged, dry, semi-sweet, sweet wines, with or without oak barrels). 
ToSEE - Tourism in Southern and Eastern Europe, Vol. 5, pp. 319-333, 2019 A. S. Ilak Peršurić, A. Težak Damijanić, Z. Šergo: THE WINE TOURISM TERROIR: EXPERIENCES ...

Field research on a sample of tourists was executed in 2015., with tourists visiting 30 wine cellars (wineries from the first sample), where 107 questionnaires were collected.

The questionnaire contained questions divided into four determinants; 1) sociodemographic determinants, 2) reasons for wine consumption, 3) wine preference, 4) aspects of wine cellars and wine tourism.

Motives for wine consumption, wine preferences, aspects of wine cellars and tourism were measured by Likert scales, ranging from 1 to 5 (1 meant "I totally disagree" to 5 that meant "I agree with the statement completely").

Since the researchers choose to collect data directly at wine cellars, during the field research some limitations were confronted, such as time and financial limits. Since the wine producers had no organized visits (like bus tours) but individual visitors, on the certain days when researchers visited the winery the number of visitors could not be predicted, therefore the sample of tourists was limited. Further not all tourists wanted to participate in the research, they came to taste wine and did not want to be disturbed. The project did not provide any incentive for the producers neither to tourists to increase their interest (because it was not an eligible cost in project funds). The limitations of producers sample were due to lack of staff and time, also the overall number of producers with wines with geographic origin was limited.

Data were subjected to standard techniques of univariate (means and percentages) and bivariate analysis (T-test, hi squared test and Pearsons' correlation variables).

Our hypothesis were the following; the terroir of Istria and the quality of wine will be highly valued wine cellar visitors; wine cellar visitors are highly involved type of consumers with higher levels of knowledge, interested in wine itineraries, gaining new knowledge and experiences about Istria wines.

\section{RESEARCH RESULTS}

\subsection{Production surfaces, wine varieties and sales of wine in Istria}

Table 1: Vineyard surfaces and wine production in Istria County

\begin{tabular}{|l|c|c|c|c|}
\hline & \multicolumn{2}{|c|}{ 2011. } & \multicolumn{2}{c|}{ 2014. } \\
\hline Variety & Ha & Hl & Ha & Hl \\
\hline Bourgogne & 48.65 & 1244.21 & 49.77 & 1121.26 \\
\hline Cabernet Sauvignon & 180.25 & 8441.70 & 189.08 & 9358.62 \\
\hline Chardonnay & 125.24 & 4935.88 & 134.06 & 4797.24 \\
\hline Malvazija Istarska & 1601.61 & 46675.14 & 1697.01 & 46917.19 \\
\hline Merlot & 302.22 & 12133.01 & 315.91 & 9718.99 \\
\hline Muscat white & 40.70 & 1025.41 & 42.19 & 886.35 \\
\hline Muscat yellow & 21.23 & 960.04 & 28.57 & 785.45 \\
\hline Muscat rose & 13.55 & 340.83 & 13.63 & 379.65 \\
\hline Pinot white & 18.56 & 584.12 & 19.40 & 288.00 \\
\hline
\end{tabular}


ToSEE - Tourism in Southern and Eastern Europe, Vol. 5, pp. 319-333, 2019 A. S. Ilak Peršurić, A. Težak Damijanić, Z. Šergo: THE WINE TOURISM TERROIR: EXPERIENCES ...

\begin{tabular}{|l|c|c|c|c|}
\hline & \multicolumn{2}{|c|}{ 2011. } & \multicolumn{2}{c|}{ 2014. } \\
\hline Variety & Ha & Hl & Ha & Hl \\
\hline Pinot grey & 13.46 & 414.57 & 18.53 & 472.39 \\
\hline Refosco & 89.92 & 2109.81 & 100.56 & 1708.53 \\
\hline Sauvignon & 13.28 & 685.43 & 16.25 & 188.30 \\
\hline Syrah & 14.36 & 782.12 & 14.74 & 378.55 \\
\hline Teran & 240.35 & 7512.96 & 251.41 & 7224.50 \\
\hline
\end{tabular}

Source: Croatian Agency for agriculture, 2011-2014.

According to the data collected by the Croatian Agency for payments in agriculture

(https://www.apprrr.hr/registri/) the surfaces under viticulture crops in Istria have grown steadily. This trend was most obvious for autochthonous grape varieties such as Malvazija Istarska, Teran and Refošk (Table 1).

Surfaces of planted Malvazija had increased for 96 hectares, while other varieties increased by less than 14 hectares (Refošk and Teran as autochthonous, Cabernet Sauvignon and Merlot as introduced varieties) in the meantime. Other wine grape varieties were less popular among producers retaining almost the same surfaces during the time interval 2011-2014.

The field data from the sample of wine producers (Table 2) shows that all producers have Malvazija in production, two-thirds produce Teran and Cabernet Sauvignon (black introduced variety), and half have Muscat yellow (autochthonous white variety), Chardonnay (introduced white variety) and Merlot (introduced black variety).

Table 2: Wine in production

\begin{tabular}{|l|c|c|c|c|}
\hline \multirow{2}{*}{ Variety } & \multicolumn{2}{|c|}{ Wine in production } & \multicolumn{2}{c|}{$\begin{array}{c}\text { Wine with protected } \\
\text { geographic origin }\end{array}$} \\
\hline & $\mathbf{N}$ & $\mathbf{\%}$ & $\mathbf{N}$ & $\mathbf{\%}$ \\
\hline Bourgogne & 4 & 11.8 & 3 & 9.7 \\
\hline Cabernet Sauvignon & 23 & 67.6 & 20 & 64.5 \\
\hline Chardonnay & 18 & 52.9 & 16 & 51.6 \\
\hline Malvazija Istarska & 34 & 100.0 & 31 & 100.0 \\
\hline Merlot & 19 & 52.6 & 14 & 45.1 \\
\hline Muscat white & 12 & 35.2 & 9 & 29.0 \\
\hline Muscat yellow & 4 & 11.8 & 2 & 6.5 \\
\hline Muscat rose & 17 & 50.0 & 13 & 41.9 \\
\hline Pinot white & 1 & 2.9 & 1 & 2.9 \\
\hline Pinot grey & 2 & 5.9 & 2 & 5.9 \\
\hline Refosco & 1 & 2.9 & 1 & 3.2 \\
\hline Sauvignon & 6 & 17.7 & 4 & 12.9 \\
\hline Syrah & 1 & 2.9 & 0 & 0.0 \\
\hline Teran & 22 & 64.7 & 4 & 12.9 \\
\hline
\end{tabular}

Source: field research, sample of producers 
ToSEE - Tourism in Southern and Eastern Europe, Vol. 5, pp. 319-333, 2019 A. S. Ilak Peršurić, A. Težak Damijanić, Z. Šergo: THE WINE TOURISM TERROIR: EXPERIENCES ...

According to the data the majority of wines in production were bottled wines, while a smaller percentage of producers produced bulk wines. The producers with bottled wines had geographic origin labels and their own (producer) labels, and all their Malvazija in production were geographically protected. Almost all Bourgogne, Chardonnay and Cabernet Sauvignon had geographic protection and producers' label. The exception was Teran which at the time of the research could not be labelled as geographically protected grape and wine variety (because of the legal battle between Republic Slovenia and Republic Croatia for the name and origin quest, finally solved in 2018 with a positive approval to both states, their producers can now use the name Teran and protect their wines).

To get more insight in the most popular grape variety, Malvazija and its largest production compared to other varieties, producers were asked which types of wines they produced from it (Table 3).

The majority produced young, fresh Malvazija, a type of wine that is produced by fast grape processing in controlled conditions and aged until the next summer (7-9 months), marketed and sold during the summer months. A smaller percentage of producers (onethird) had also other types of Malvazija, such as ripened in oak barrels for shorter or longer periods (2-20 years) or in barrique barrels.

From the findings in the questionnaire at the producers' wine cellars it is obvious that Malvazija has shown its various potentials as a young, aged, dry, semisweet and sweet wine that can be sold in bulk and in bottles.

Table 3: Types of Malvazija Istarska wines in production and sales

\begin{tabular}{|c|c|c|c|}
\hline & & $\mathbf{N}$ & $\%$ \\
\hline \multirow{3}{*}{ Type by ageing } & Young & 33 & 97.1 \\
\hline & Aged & 13 & 38.2 \\
\hline & Other (late harvest) & 4 & 11.7 \\
\hline \multirow{3}{*}{ Type by sweetness } & Sweet & 2 & 5.9 \\
\hline & Semi sweet & 1 & 2.9 \\
\hline & Dry & 31 & 91.2 \\
\hline \multirow{2}{*}{ Type by package } & Only bottles & 4 & 11.8 \\
\hline & Bulk and bottles & 30 & 88.2 \\
\hline \multirow{2}{*}{$\begin{array}{l}\text { Type by ripening in } \\
\text { barrique }\end{array}$} & Yes & 4 & 11.8 \\
\hline & No & 30 & 88.2 \\
\hline \multirow{3}{*}{$\begin{array}{l}\text { Sales in last three } \\
\text { years }\end{array}$} & Increased & 16 & 80.0 \\
\hline & Diminished & 1 & 5.0 \\
\hline & Equal & 4 & 15.0 \\
\hline \multirow{5}{*}{ Location of sales } & Locally (wine cellar and nearby) & 28 & 91.2 \\
\hline & Regional (Istria) & 31 & 82.4 \\
\hline & Nacional (Croatia) & 28 & 64.7 \\
\hline & EU & 22 & 47.1 \\
\hline & World & 16 & 23.5 \\
\hline
\end{tabular}

Source: field research, sample of producers 
ToSEE - Tourism in Southern and Eastern Europe, Vol. 5, pp. 319-333, 2019 A. S. Ilak Peršurić, A. Težak Damijanić, Z. Šergo: THE WINE TOURISM TERROIR: EXPERIENCES ...

The potential market for the majority of producers is at their wine cellar door, open to visitors whole year around or at certain months and daily hours. Istria as the region and as the local market is of great importance for sales. Prominent producers have sold Malvazija in at least one EU country, and the positive aspect of wine sales is that almost half of the responding producers had such sales strategies. Furthermore each fourth producer sold their Malvazija worldwide. These two sets of data show that Malvazija is recognized and attractive to foreign markets and seen as already an established market product.

Producers used both direct and indirect channels of sales, whereas the sales at cellar doors were most used (Table 4). For the producers this type of sales offers an opportunity to present the wine in the best possible way; close to the production site (vineyards and wine cellar), directly in contact with the producer who can explain all positive aspects and attributes of their wine, present it in optimal surrounding (in the wine cellar, with professional wine glasses, at optimal temperature) and recommend its pairing with food and occasion.

Table 4: Distribution of Malvazija Istarska wines

\begin{tabular}{|l|c|c|}
\hline Chanels of distribution in last three years & Frequency & \% \\
\hline Own wine cellar & 32 & 94.1 \\
\hline Wine boutique & 19 & 55.8 \\
\hline Small shops & 11 & 32.4 \\
\hline Retail chains & 8 & 23.5 \\
\hline Restaurants & 31 & 91.2 \\
\hline Agro tourism & 3 & 8.8 \\
\hline Internet & 8 & 23.5 \\
\hline Other (distributers, gift packages) & 10 & 29.4 \\
\hline
\end{tabular}

Source: field research, sample of producers

\subsection{Wine cellar visitors and their motives for visiting Istria and wine tasting}

The sample of wine cellar visitors showed that men were more frequent in visiting wine cellars in comparison to women (Table 5).

The prevailing age of visitors was 35 to 44 years of age. Younger persons (under 34 years of age) were less frequent visitors. Majority of wine cellar visitors were highly educated, what also reflected to their monthly incomes, one-fifth had very high incomes (over 4000 $€)$. Prevailing types of employment were in demanding, high involvement and high knowledge types of employments, either as owner of a business, an entrepreneur or manager.

To determine which features of wines were attractive to wine cellar visitors we have included a set of questions about so called wine attributes (Table 6). It was noticed that personal relationships had great impact on which wine will be chosen at the wine cellar, tasted and eventually purchased there. 
ToSEE - Tourism in Southern and Eastern Europe, Vol. 5, pp. 319-333, 2019 A. S. Ilak Peršurić, A. Težak Damijanić, Z. Šergo: THE WINE TOURISM TERROIR: EXPERIENCES ...

Table 5: Socio economic descriptors of wine cellar visitors

\begin{tabular}{|c|c|c|}
\hline \multicolumn{2}{|c|}{ Socio-demographic and economic indicators } & \multirow{2}{*}{$\begin{array}{c}\text { Percentage } \\
63 \%\end{array}$} \\
\hline & Male & \\
\hline Gender & Female & $37 \%$ \\
\hline \multirow{5}{*}{ Age } & Up to 24 & $12 \%$ \\
\hline & $25-34$ & $17 \%$ \\
\hline & $35-44$ & $36 \%$ \\
\hline & $45-54$ & $20 \%$ \\
\hline & $55+$ & $15 \%$ \\
\hline \multirow{3}{*}{ Education } & Primary & $1 \%$ \\
\hline & Secondary & $39 \%$ \\
\hline & Higher / faculty & $60 \%$ \\
\hline \multirow{6}{*}{ Employment } & $\begin{array}{l}\text { Entrepreneur/ own business } \\
\text { / self employed }\end{array}$ & $31 \%$ \\
\hline & Employee & $32 \%$ \\
\hline & Manager & $20 \%$ \\
\hline & Pupil / student & $10 \%$ \\
\hline & Retired & $4 \%$ \\
\hline & Other & $3 \%$ \\
\hline \multirow{5}{*}{ Monthly income } & Up to $1.000 €$ & $26 \%$ \\
\hline & $1001-2000 €$ & $29 \%$ \\
\hline & $2001-3000 €$ & $19 \%$ \\
\hline & $3001-4000 €$ & $6 \%$ \\
\hline & Over $4000 €$ & $20 \%$ \\
\hline
\end{tabular}

Source: field research, sample of wine cellar visitors

Table 6: Importance of wine attributes to wine cellar visitors

\begin{tabular}{|l|c|c|}
\hline Wine attribute & Range & Average grade \\
\hline Recommendations of friends & 1 & 4.06 \\
\hline Quality (PDO, PGI labels) & 2 & 3.91 \\
\hline Amount of sugar & 3 & 3.88 \\
\hline Price of wine & 4 & 3.56 \\
\hline Recommendations of waiters & 5 & 3.51 \\
\hline Awards & 6 & 3.42 \\
\hline Recommendations of sellers & 7 & 3.36 \\
\hline Terroir / locality & 8 & 3.38 \\
\hline The age of wine & 9 & 3.35 \\
\hline Micro region / wine region Istria & 10 & 3.33 \\
\hline Winery name/ label & 11 & 3.04 \\
\hline Discounts & 12 & 3.02 \\
\hline
\end{tabular}

Source: field research, sample of wine cellar visitors 
ToSEE - Tourism in Southern and Eastern Europe, Vol. 5, pp. 319-333, 2019 A. S. Ilak Peršurić, A. Težak Damijanić, Z. Šergo: THE WINE TOURISM TERROIR: EXPERIENCES ...

The attributes of quality were ranked as most important and the distinction was made upon the preference to the content of sugar (dry wines dominating). The price of wine was the most important economic attribute, while discounts were of very low importance. The terroir and the micro location where the vineyards were situated were more important to wine tourists then the wine region of Istria, showing that questioned persons already recognize Istria as a wine region and are familiar with its offerings. The importance of wine terroir showed that questioned persons had considerable knowledge about the wines and could distinguish particular wine terroirs and micro regions.

Since most wine tourists came to particular wine cellars upon the recommendation of their friends and family members (around 60\%) it can be presumed that previous positive experiences of these persons positively affected the choice of visited wine cellars and the choice of Istria as a destination for vacation. Implications of prior visits had influenced visitors in our to visit Istria, to take a long distance travel of several days (all wine cellar visitors were staying in Istria two up to fifteen days) and motivated them to visit wine cellars.

The destination image of Istria as a wine terroir in a cognitive sense (resources and attractions) was evoked through resources of the wine cellars, natural and cultural resources in the area (Table 7).

Table 7: Elements of Istria wine tourism terroir

\begin{tabular}{|c|c|c|c|}
\hline Variable & $\mathbf{M}$ & SD & $\begin{array}{l}\text { Pearson } \\
\text { correlation }\end{array}$ \\
\hline Perception of Malvasia Istarska as autochthonous wine & 3.75 & 0.875 & 1.000 \\
\hline \multicolumn{4}{|c|}{ Winery visitation motives } \\
\hline Wine tasting & 2.70 & 1.284 & $0.302 * *$ \\
\hline Interested in wines & 3.81 & 1.100 & $0.357 * * *$ \\
\hline To learn something new related to wine & 3.96 & 0.946 & $0.313 * *$ \\
\hline Personal contact with wine maker & 3.60 & 1.147 & $0.387 * * *$ \\
\hline Getting to know Istria better & 3.61 & 0.956 & $0.275^{* *}$ \\
\hline Having fun with friends & 3.68 & 1.095 & 0.138 \\
\hline Business & 2.21 & 1.395 & $0.459 * * *$ \\
\hline \multicolumn{4}{|c|}{ Wine itineraries elements } \\
\hline Wine tastings in wineries & 3.88 & 0.938 & $0.251 *$ \\
\hline Gastronomy & 3.79 & 0.951 & $0.279 * *$ \\
\hline Natural heritage & 3.75 & 1.031 & $0.227 *$ \\
\hline Cultural heritage & 3.71 & 1.065 & 0.124 \\
\hline
\end{tabular}

Source: field research, sample of wine cellar visitors,

Note: *significant at $\alpha=0.05, * *$ significant at $\alpha=0.01 . * * *$ significant at $\alpha=0.001$

In the affective sense (feelings, emotions), Istria as a wine terroir was valued through socializing effects (socializing with family and friends, relaxing moments and interaction with the wine producer). 
ToSEE - Tourism in Southern and Eastern Europe, Vol. 5, pp. 319-333, 2019 A. S. Ilak Peršurić, A. Težak Damijanić, Z. Šergo: THE WINE TOURISM TERROIR: EXPERIENCES ...

Visits to the wine cellar were mostly organized by the questioned persons (65\%), family $(12 \%)$ or friends $(19 \%)$ and very rare by tourist agencies $(2 \%)$. The visitors were accompanied by partner and children $(40 \%)$ or friends $(52 \%)$.

Therefore, it might presumed that positive experiences of respondents in the sample and their experiences and knowledge about Istria in general and as a wine region might be transferred to other family members and acquaintances and might be followed in the future with more visits and further positive recommendations.

To gain insight into which elements of Istria as a wine terroir are important for wine cellar visitors, we have divided them in three main elements; wine, winery visitation motives and wine itineraries elements.

Table 8: Differences between tourist highly interested and less interested in elements of wine tourism terroir in Istria

\begin{tabular}{|c|c|c|c|c|c|}
\hline \multirow[t]{2}{*}{ Variables } & \multicolumn{2}{|c|}{$\begin{array}{l}\text { Less } \\
\text { interested }\end{array}$} & \multicolumn{2}{|c|}{$\begin{array}{l}\text { Highly } \\
\text { Interested }\end{array}$} & \multirow[t]{2}{*}{ t- test } \\
\hline & M & SD & $\mathrm{M}$ & SD & \\
\hline \multicolumn{6}{|l|}{ Winery visitation motives } \\
\hline Wine tasting & 2.07 & 1.033 & 2.82 & 1.297 & $-2.122 *$ \\
\hline Interested in wines & 3.13 & 1.060 & 3.91 & 1.068 & $-2.608 *$ \\
\hline $\begin{array}{l}\text { To learn something new related to } \\
\text { wine }\end{array}$ & 3.20 & 1.207 & 4.10 & 0.831 & $-2.765^{*}$ \\
\hline Personal contact with wine maker & 3.00 & 1.069 & 3.72 & 1.132 & $-2.269 *$ \\
\hline Getting to know Istria better & 3.14 & 0.864 & 3.70 & 0.952 & $-2.030 *$ \\
\hline Having fun with friends & 3.33 & 1.175 & 3.74 & 1.081 & -1.315 \\
\hline Business & 1.67 & 0.976 & 2.32 & 1.444 & $-2.153 *$ \\
\hline \multicolumn{6}{|l|}{ Wine itineraries elements } \\
\hline Wine tastings in wineries & 3.40 & 1.121 & 3.96 & 0.887 & $-2.164 *$ \\
\hline Gastronomy & 3.33 & 0.976 & 3.84 & 0.923 & -1.944 \\
\hline Natural heritage & 3.47 & 1.125 & 3.80 & 1.018 & -1.135 \\
\hline Cultural heritage & 3.56 & 1.413 & 3.73 & 0.996 & -0.463 \\
\hline
\end{tabular}

Source: field research, sample of wine cellar visitors

Note: *significant at $\alpha=0.05, * *$ significant at $\alpha=0.01$. ***significant at $\alpha=0.001$

A statistically significant difference was detected between visitors' prior consumption of Malvasia Istarska and their general habit of visiting wineries during vacation travels $(\chi$ $=16,767, \mathrm{df}=1, \alpha=0.000)$ as well interest in wine itineraries in the vacation destination $(\chi=6,894, \mathrm{df}=1, \alpha=0.018)$. There were more winery visitors with prior experience in consumption of Malvasia Istarska with a habit of visiting wineries during vacation and with interest in wine itineraries in vacation destination compared to those with no prior experience in consumption of Malvasia Istarska.

The questioned persons which loved wines were more satisfied meeting the wine producers $(\chi=6,7, \mathrm{df}=2, \alpha=0.009, \mathrm{Cc}=0.498)$, were more interested in knowing Istria better $(\chi=4,8, \mathrm{df}=1, \alpha=0.000, \mathrm{Cc}=0453)$ and were strongly motivated by wine tasting $(\chi=8,2, \mathrm{df}=1, \alpha=0.008)$. 
ToSEE - Tourism in Southern and Eastern Europe, Vol. 5, pp. 319-333, 2019

A. S. Ilak Peršurić, A. Težak Damijanić, Z. Šergo: THE WINE TOURISM TERROIR: EXPERIENCES ...

Winery visitation motives item means varied from 2.21 ('Business') to 3.96 ('To learn something new related to wine'), while Wine itineraries elements item means varied from 3.71 ('Cultural heritage') to 3.88 ('Wine tastings in wineries').

Both, winery visitation motives and wine itinerary elements, were positively correlated to perception of Malvasia Istarska as autochthonous wine. These relationships were mostly statistically significant, but not highly correlated. In general, the responders who were interested in wine itineraries gave higher importance to winery visitation motives and wine itineraries elements. Statistically significant differences were identified between those responders who were interested and not interested in wine itineraries in regard to six winery visitation motives and one wine itineraries element.

\section{CONCLUSION}

From our survey, we noticed that visitors of wine cellars in Istria were interested in wine and wine itineraries. Their visit to Istria was "pushed" by previous experiences of their friends and family members. The main "push" factor was Istria as a destination for a vacation. During their long term vacation in Istria they organized by themselves or by friends and family members' visits to wine cellars. The socializing effects were a major "push" factor, since half of questioned wine cellar visitors came with friends and $42 \%$ came with family members.

"Pull" factors were comprised of elements of the wine terroir, namely, wine (learning something new about wines), activities (wine tasting), new knowledge (getting to know Istria better, meeting the wine producer) and itineraries with wine, gastronomic offerings and complementary natural and cultural attractions.

The current positive identity of Istria and positive advertising presents the territory with numerous possibilities for vacations, while various niche tourism offers attract more demanding tourists.

In the case of wine tourism the terroir of Istria was already recognized by tourists relying on the existing identity, advertise and territory of Istria as a tourist destination. The added value of viticulture and viticulture terroir was a reflection of land, soil, climate and vineyards in which autochthonous wine grapes were grown. Malvazija Istarska as most produced grape variety and most important wine in production and sales (80\% of total production) with increasing demand and sales was chosen as an example of autochthonous wine by which we have examined the behavior of wine cellar visitors. Several types of Malvazija Istarska were offered, dry, semi-sweet, sweet, fresh or aged, with or without ageing in oak barrels, bottled and in bulk. The offering of Malvazija Istarska in wine cellars was very important to producers (94\% sold wine this way), and as a direct sales channel, it allowed the producer to present the product in the best possible way, while the cellar visitors had an opporunity to taste the wine and learn something new about them through the personal contact with the wine producer. 
ToSEE - Tourism in Southern and Eastern Europe, Vol. 5, pp. 319-333, 2019 A. S. Ilak Peršurić, A. Težak Damijanić, Z. Šergo: THE WINE TOURISM TERROIR: EXPERIENCES ...

Wine cellars visitors valued very highly wine attributes such as quality, price, awards, terroir and micro region. Their choice of a certain Malvazija was strongly influenced by recommendations of friends and their previous experiences in wine consumption and in wine cellars.

Differences among wine cellar visitors were noticed upon their interest for wine itineraries, whereas those who were interested ranked higher all elements of the wine terroir Istria.

Therefore the dimensions of the wine terroir of Istria are currently comprised by the product (wine and related products), natural dimensions (landscape, vineyards, wine roads) and activities (wine tastings, visits to wineries).

From our findings we can recommend that the wine terroir Istria should follow the positive trends of Malvazija Istarska as an autochthonous wine and grape variety recognized by tourists. The promotion should remain on its attributes of quality, awards, terroir and micro location.

Possibilities for future development of Istria wine terroir lie in high interested tourists for whom more activities (events) and new itineraries should be created. These activities should provide new experiences for visitors and time in socializing with their friends and family members.

\section{REFERENCES}

Chrysochou, P. and Jorgensen, J.B. (2016), "Danish consumer preferences for wine and the impact of involvement", 9th Academy of wine business research Conference proceedings, AWBR and University of South Australia, Adelaide, Australia, pp. 194-202.

Colours of Istria, Official pages of North west Istria, viewed 12. January 2019, https://www.coloursofistria.com/en/destinations/istria,

Combris, P., Bazoche, P., Giraud-Heraud, E. and Issanchou, S. (2009), "Food choices: What do we learn from combining sensory and economic experiments?" Food quality and Preference, Vol. 20, No. 8, pp 550-557 https://doi.org/10.1016/j.foodqual.2009.05.003

Dann, G. (1977), “Anomie, ego-enhancement and tourism”, Annals of Tourism Research, Vol. 4, No. 4, pp 184-194.

Dann, G. (1981), "Tourist motivation: An appraisal”, Annals of Tourism Research, Vol. 8, No. 2, pp. 187-219.

Eldesouky, A. and Mesias, F. (2014), "An insight into the influence of packaging and presentation format on consumer purchasing attributes towards a cheese: a qualitative study", Spanish Journal of Agricultural Research, Vol. 12, No. 2, pp. 305-312 doi: 10.5424/sjar/2014122-5520

Getz, D. and Brown, G. (2006), "Critical success factors for wine tourism regions: a demand analysis", Tourism Management, No. 27, pp. 146-158 https://doi.org/10.1016/j.tourman.2004.08.002

Getz, D. (2000), Explore wine tourism: Management, development \& destinations, Cognizant Communication Corporation, New York, NY, pp. 254

Gomez, M., Molivia, A. and Esteban, A. (2013), "What are the main factors attracting visitors to wineries? A PLS multi group comparison", Quality and Quantity, No. 47, pp. 2637-2657 https://doi.org/10.1007/s11135-012-9676-5

Hall, C.M., and Mitchell, R. (2002), "The touristic terroir of New Zealand wine: the importance of region in the wine tourism experience", pp. 69-91. In Montanari, A. (Ed.), Food and environment: geographies of taste, Societa Geographica Italiana, Italy, $127 \mathrm{pp}$.

Holland, T., Smit, B. and Jones, G.V. (2014), "Toward a conceptual framework of terroir tourism: A case study of the Prince Edward County, Ontario Wine Region”, Tourism Planning \& Development, Vol. 11, No. 3, pp. 275-291 doi.org/10.1080/21568316.2014.890125 
ToSEE - Tourism in Southern and Eastern Europe, Vol. 5, pp. 319-333, 2019

A. S. Ilak Peršurić, A. Težak Damijanić, Z. Šergo: THE WINE TOURISM TERROIR: EXPERIENCES ...

Ilak Peršurić, A.S. (2018), "Examples of European Tourism destinations and importance of Agricultura Landscapes", Fourth International Scientific Conference Proceedings ERAZ 2018, Association of Economists and Managers of the Balkans, Sofia, Bulgaria, pp. 606-615.

Ilak Peršurić, A.S., Težak Damijanić, A. and Kerma, S. (2018), "The relationship between autochthonous wine attributes and wine consumption motives", Economics of agriculture, No. 4, pp. 1329-1656 doi:10.5937/ekoPolj1804337I

Istria gourmet, viewed 08. April 2019, http://www.istria-gourmet.com/hr/gurmanski-dozivljaji

Istria tourist board official website, viewed 08. April 2019, https://www.istra.hr/hr

Kallas, Z., Escobar, C. and Gill, J. (2012), "Assessing the impact of Christmas advertisement campaign on Catalan wine preference using choice experiments", Appetite, No. 52, pp. 285-298 doi.org/10.1016/j.appet.2011.09.017

Kim, H. and Bonn, M.A. (2014), "Types of Wine Tourists, Authenticity and Behavioral Intentions in the Wine Business", Journal of International Trade \& Commerce, No. 10, pp. 53-67 doi:10.16980/jitc.10.3.201406.53

Koch, J., Martin, A. and Nash, R. (2013), "Overview of perceptions of German wine tourism from the winery perspective", International Journal of wine Business Research, Vol. 25, No. 1, pp. 50-74 doi/full/10.1108/17511061311317309

Lockshin, L., Jarwis, W., d'Hautville, F. and Perrouty, J.P. (2006), "Using simulations from discrete choice experiments to measure consumers sensitivity to brand, region, price and awards in wine choice", Food quality and preference, No. 17, pp. 166-178 https://doi.org/10.1016/j.foodqual.2005.03.009

Lopes, P., Sagala, R. and Lockshin, L. (2016), "Importance of eco-logo and closure type on consumer expectations, price perception and willingness to purchase wines in Canada", AAWE working paper 200, AAWE conference, AAWE, Bologna, Italy.

Marlowe, B. and Lee, S. (2018), "Conceptualizing terroir wine tourism", Tourism Review International Vol. 22, pp. 143-151 doi.10.3727/154427218X15319286372298

Marzo-Navarro, M. and Iglessias, M.P. (2012), "Critical factors of wine tourism: incentives and barriers from the potential tourist's perspective", International Journal of contemporary Hospitality Management Vol. 24, No. 2, pp. 312-334 https://doi.org/10.1108/09596111211206196

Matos Graça Ramos, P., Martins, F.V. and Gouveia Barandas, H. (2011), "Differences in the Perception of Wine Attributes: A Comparative View Between Consumers, Producers and Intermediaries", Bulletin de l'OIV, No. 84, pp. 271-306.

Melo, L., Colin, J., Delahunty, C, Forde, C. and Cox, D.N. (2010), "Lifetime wine drinking, changing attitudes and associations with current wine consumption: A pilot study indicating how experience may drive current behavior", Food quality and Preference No. 21, pp. 784-790 https://doi.org/10.1016/j.foodqual.2010.07.012

Registry of payments in agriculture, Agency of payments in agriculture, fishery and rural development, Department public relations, viewed 12. January 2019, https://www.apprrr.hr/registri/

Tempesta, T., Arboretti Giancristofaro, R., Coraina, L., Salmasoa, L., Tomasic, D. and Boatto, V. (2010), "The importance of landscape in wine quality perception: An integrated approach using choice-based conjoint analysis and combination-based permutation tests", Food Quality and Preference, Vol. 21, No. 7, pp. 827-836 doi.org/10.1016/j.foodqual.2010.04.007

Težak Damijanić, A., Ilak Peršurić, A.S. and Luk, N. (2015), "Malvazija Istarska kao sadržaj turističkog proizvoda Istarske županije", $50^{\text {th }}$ Croatian agronomist conference proceedings, University J.J. Strossmayer, Osijek, Faculty of agriculture, Opatija, Croatia, pp. 179-183.

Yuan, J., Liping, C.A., Morrison, M.A. and Linton S. (2005), "Segmenting wine festival attendees: A factor cluster approach", Tourism Review International, No. 8, pp. 297-309 https://doi.org/10.3727/154427205774791500

Verdonk, N.R., Wilkinson, J.W., Culbert, J.A., Ristic, R., Lane, M.J. Pearce, K.L. and Wilkinson K.L. (2016), "Australian consumers perceptions of Champagne and other sparkling wine: an exploratory study", 9th Academy of wine business research conference, Conference proceedings, AWBR and University of South Australia, Adelaide, Australia, pp.184-193.

Vinistra, wine producers association, viewed 08. April 2019, http://www.vinistra.com/ 
ToSEE - Tourism in Southern and Eastern Europe, Vol. 5, pp. 319-333, 2019

A. S. Ilak Peršurić, A. Težak Damijanić, Z. Šergo: THE WINE TOURISM TERROIR: EXPERIENCES ...

Anita Silvana Ilak Peršurić, $\mathrm{PhD}$, Scientific advisor

Institute of agriculture and tourism,

Department of Economics and Rural development

K. Hugues 8, Poreč, Croatia

Phone: +385-52-408329

E-mail: anita@iptpo.hr (corresponding author)

Ana Težak Damijanić, $\mathrm{PhD}$, Scientific associate Institute of agriculture and tourism,

Department of Tourism

K. Hugues 8, Poreč, Croatia

Phone: +385-52-408300

E-mail: tezak@iptpo.hr

Zdravko Šergo, PhD, Scientific advisor

Institute of agriculture and tourism,

Department of Tourism

K. Hugues 8, Poreč, Croatia

Phone: +385-52-408328

E-mail: zdravko@iptpo.hr 